\title{
"The impact of transforming bank advisory services to borrowers on non-interest revenue generation"
}

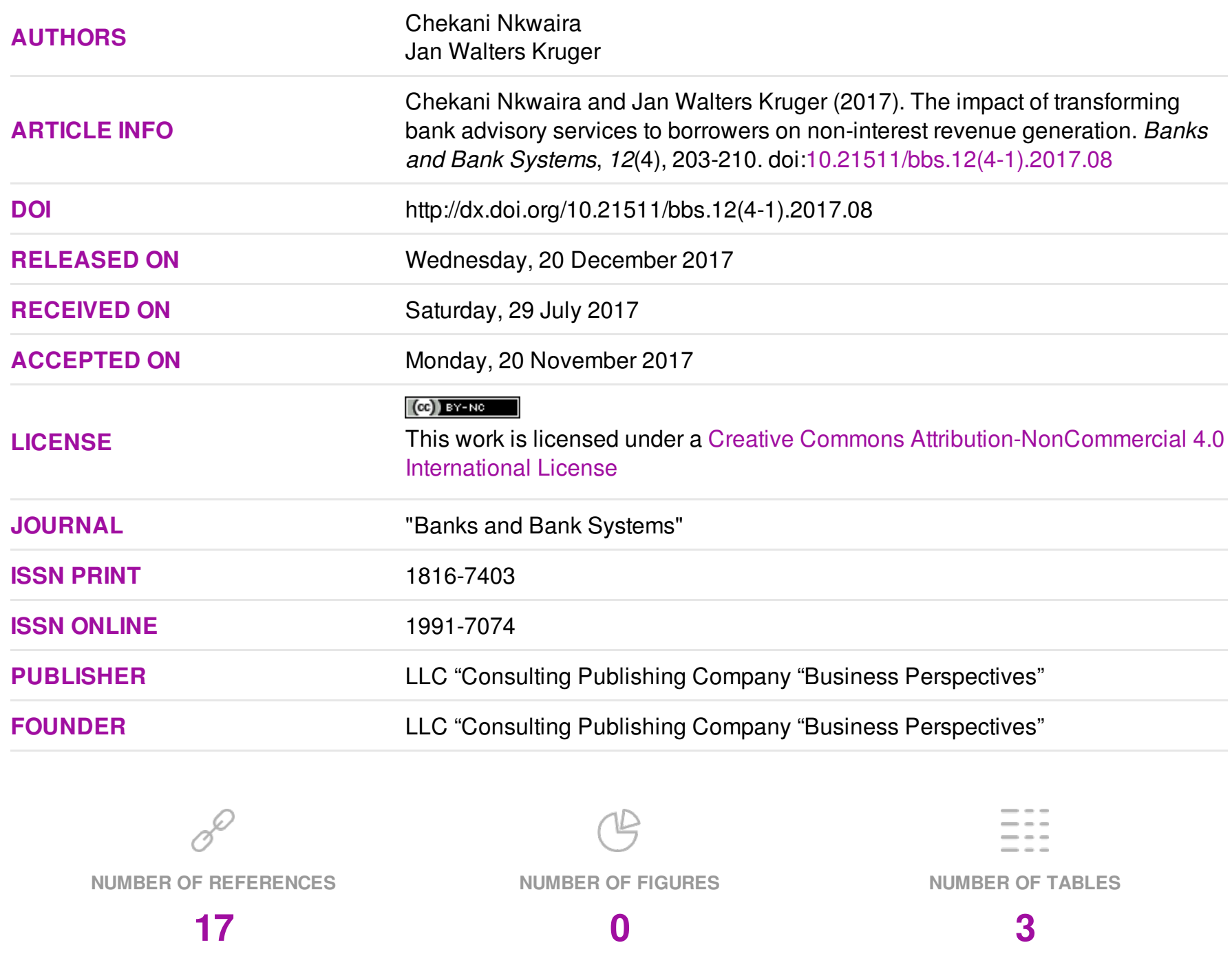

(C) The author(s) 2023. This publication is an open access article. 


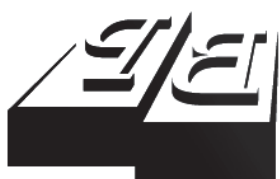

BUSINESS PERSPECTIVES

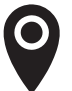

LLC "CPC "Business Perspectives" Hryhorii Skovoroda lane, 10, Sumy, 40022, Ukraine

www.businessperspectives.org

Received on: $29^{\text {th }}$ of July, 2017 Accepted on: 20 th of November, 2017

(c) Chekani Nkwaira, Jan Walters Kruger, 2017

Chekani Nkwaira, Doctor of Business Leadership, University of South Africa, South Africa.

Jan Walters Kruger, Professor of Corporate Finance, School of Business Leadership, University of South Africa, South Africa.

\section{(ㄷ)(1) $(8)$}

This is an Open Access article, distributed under the terms of the Creative Commons Attribution-NonCommercial 4.0 International license, which permits re-use, distribution, and reproduction, provided the materials aren't used for commercial purposes and the original work is properly cited.

\section{THE IMPACT OF TRANSFORMING BANK ADVISORY SERVICES TO BORROWERS ON NON-INTEREST REVENUE GENERATION}

\begin{abstract}
The challenges of revenue generation by banks are evident if one considers the accusations labelled against the banks of aggressive lending (Archaya \& Naqvi, 2012), which basically centers on the pursuit of profits with minimum regard to risk management. If not read or if read in passing, loan terms can be used to destroy the reputation of banks when accusations of predatory loans surface. It is argued here that even if understood at the time of signing the acceptance of the loan, there is no guarantee that the terms are still top of mind of borrowers, especially those who borrow for a long term. Banks can use their advisory skills to periodically take borrowers through loan terms, confirm understanding, detect any wanton behaviors (WB) from borrowers' financial activities that go against financial astuteness and may jeopardize repayment capabilities and offer advice on practices that are not counter to repayment capabilities. Banks can mitigate the challenges in interest income generation, particularly from a default point of view by periodically engaging borrowers to specifically advice on behavioral issues that manifest themselves in financial levers. Since borrowers stand to gain immeasurable value out of these engagements, banks can justifiably levy borrower advisory service fees (BASF) and wanton hazard fee (WHF). The authors show, through the application of the BASF and WHF, the potential income banks can generate. Using the BASF and WHF as sources of non-interest income, the potential benefit taking into account the credit loss as a function of BASF accruing to the bank is established.
\end{abstract}

\section{Keywords}

\section{JEL Classification}

borrower advisory service fee, wanton behavior, loan terms, periodic assessment, wanton hazard fee

\section{INTRODUCTION}

We identify WB which is self-destructive behavior, in borrower aggression and macroeconomic fundamentals that need to be highlighted as part of the levers that should be looked into periodically based on their implications as stated on loan terms. Loan terms should, therefore, explicitly include a section of what is considered wanton. Identification of WB and the commensurate advice is similar to a credit enhancement process, i.e. risk mitigation measures on the borrower's side.

An important aspect that needs periodic assessment is WB by borrowers in pursuit of profitability via sales growth which is a key cash driver. Wanton behavior shows up when due to neglect of managing risk borrowers aggressively chase profits by extending collection periods so as to entice more customers. This scenario puts the borrower back in the same situation that may have prompted him to apply for the facility in the first place. If no further facility can be provided, default is imminent. Cash to repay the existing facility on time is no longer there. Banks should place this scenario for assessment periodically and advise borrowers about the dangers associated with it. BASF can justifiably be levied. 
Since the availability of cash is crucial in loan repayments to banks as demonstrated by the liquidity measure which establishes if a business is generating enough cash from day to day operations to cover all normally occurring expenses, including interest and debt amortization, it follows that businesses should safeguard against raising additional cash through further borrowings from unofficial channels such as the so called loan sharks in order to generate enough cash to repay the bank a situation akin to cash flow from financing activities. This behavior is tantamount to wanton behavior because if the additional cash is not from day to day operations, it helps in repayments in the shorter term but eventually incapacitates the business' ability to repay the bank. Banks have got an advisory role to play on a periodic basis. Levying an advisory fee is clearly justifiable.

Jubilance and exuberance combined tend to make borrowers not to read the fine line when it comes to loan terms. Sometimes banks are accused of extending costly subprime loans and predatory loans and lacking transparency in divulging the real meaning of loan terms. This accusation immediately calls for banks to periodically review the understanding of loan terms by borrowers until maturity of the loan. Such a practice entails that banks avoid taking advantage of hidden financial jargon that may end up seeing the borrower being required to pay magnified interest rates. By reviewing the understanding of loan terms and ensuring that borrowers are kept reminded of loan terms, banks can play a pivotal role in mitigating defaults and foreclosures. Once borrowers are not in a position to apprehend loan terms, those terms become predatory in the event that the borrower embarks on conduct resembling WB thereby finding it difficult to afford repayments as conditions change. Periodic assessments of potential WB should be carried out and accompanied by BASF. Furthermore, periodic assessment of defaults caused by behaviors akin to WB should also be carried out and accompanied by WHF.

\section{OBJECTIVES}

The main objective of this paper is to demonstrate the feasibility in banks to generate income, particularly non-interest income by adding value to borrowers. By addressing borrower behavior that can be described as wanton (behaviors that are at odds with fulfilling repayment abilities despite a highlight of consequences of such behaviors under the terms and conditions of the loan facilities) banks can justify generating fees that can add to their non-interest revenue and at the same time mitigating loan defaults.

\section{LITERATURE REVIEW}

Apart from eroding household wealth, loans of these nature, whereby they are termed bad, also increase negative impacts on individuals, households, and communities (Quercia et al., 2007). Indeed, there are borrowers who are oblivious to the loan terms and contractual agreements, including those whose borrowing terms are long. In assessing whether borrowers know their mortgage terms, Bucks and Pence (2008) established that borrowers who could experience large payment changes if interest rates rose were more likely to indicate the absence of knowledge pertaining to contract terms. It is therefore argued here that the practice of going through the loan terms periodically is non-negotiable. Most borrowers can obtain real value out of this practice and paying BASF would not be questionable. Yet, despite the existence of strategic defaulters (Trautmann \& Vlahu, 2013) that is, solvent borrowers who are likely to default strategically when the bank's expected strength is low, there exist those whose defaulting ways are not strategic but rather reckless because of failure to take heed of signals pertaining to the chances of changes, say, in economic fundamentals such as interest rates. This occurrence provides good grounds for banks to adopt a parallel strategy that seeks to mitigate potential defaults and contemporaneous BASF by engaging borrowers and elucidating the pros and cons of such changes. The mere fact that macroeconomic changes can affect the levels of non-performing loans demands that banks look at them from a different viewpoint than before. Evidently, Klein (2013) discovered that non-performing loans were found to respond to macroeconomic conditions. The different view point calls upon banks to consistently and periodically assess financial conduct in line with those 
macroeconomic changes. For example, a business that is heavily dependent upon mining workers to consume its products should be advised to reduce inventory levels when the levels of employment in the mining sector have gone down due to various reasons such as retrenchments or mere competitiveness. Increasing inventory levels would boil down to WB and WHF should kick in.

The whole idea of generating BASF, WHF and putting an emphasis on the need to curb WB is to reform the banking sector rather than eradicating existing risk methodologies. As part of the responses to the financial crisis, Grosse (2012) focused on the inability of the market to channel participants' behavior in sustainable directions. The intention is this regard is for banks to channel borrower behavior in sustainable ways resulting in the mitigation of defaults and the commensurate BASF.

It is evident that banks can assist borrowers by assessing and explaining the effect of macroeconomic fundamentals on repayment capabilities, since, as argued by Anagnostopoulou and Drakos (2016), macroeconomic fundamentals significantly explain the "package of loan terms and conditions offered to corporate borrowers". Apart from demonstrating risk astuteness, such practices also confirm that banks are interested not only in protecting their assets but also in enhancing financial astuteness of their clients. According to Graafland and Vande Ven (2011), a return to the core virtues in the financial sector will only be successful if a renewed sense of responsibility would take precedence with due-care being one of the core virtues. Accordingly, assisting borrowers in this manner entails an inclination by banks towards due-care through advising borrowers on behaviors that are financially sound and contribute to borrowers' capacity to fulfill loan commitments. Furthermore, the dynamic nature of macroeconomic fundamentals means the ongoing need to assess the effect on borrowers accompanied by the provision of safeguarding principles to maintain affordability is ever present. Hence, loan terms themselves should be revisited with the borrower on a periodic basis to ensure to keep the understanding and the prevention of wanton behavior front and center. However, what can be referred to small business in one country can be a big business in another and a big business can be referred to as corporate in another. The impact of changes in macroeconomic factors can equally lead to massive defaults if borrowers wantonly disregard measures that can mean they safeguard against defaulting.

Motivated by the idea that both macroeconomic and bank specific variables impact the quality of loans, Louizis and Metaxas (2012) demonstrated that non-performing loans in the Greek banking system could be explained essentially by macroeconomic variables (GDP, unemployment, interest rates, and public debt). An extended view of identifying these variables in order to provide for a sustained reduction in their impact on defaults to borrowers who do not adjust their behavior in line with the vicissitudes of the stated fundamentals is sought. Consequently, revenue can be derived through directing the thinking of bank executives towards assisting borrowers to exhibit behaviors aligned to those fluctuations.

Normal operating expenses are a key cash driver and as such should be administered in such a way as to keep in touch with inflationary levels. Not only does an above inflationary increase in normal operating expenses affect liquidity which is a financial risk thereby affecting repayment capabilities. Wanton behavior entails not paying attention to inflation with regard to controllable operating expenses. A borrower who increases his operating expenses by wantonly increasing salaries of his workers to levels way above inflation and jeopardize his repayment abilities should be classified as one who embarks on a wanton behavior. BASF can be generated by advising borrowers on safety of margins in terms of operating expense increases informed by inflation.

The cash conversion cycle of most businesses is determined by the average age of inventory, the average collection period and average payment period. It is incumbent upon banks to ensure they expound to borrowers periodically the risk to repayment capabilities when borrowers engage in efforts to increase profitability by enticing customers to buy their products and services through extending the average collection period without changing the other two components of the cycle, either by shortening the average age inventory or lengthening the average payment period. Since merely 
extending the average collection period will result in a longer cash conversion cycle, downside risk accrues to both the borrower and the bank in the form of a lengthened cash conversion and a potential of inadequate cash to repay bank loans respectively. The temptation to increase profits at the expense of risk management is inherent in businesses including banks themselves who were accused of aggressive lending which involved lapse risk management procedures during the period prior to the 2007-2009 financial crisis. The only difference in this regard is that banks themselves get affected by borrowers' aggression (WB) when default becomes apparent. Banks should display agility and nimbleness in adopting the mandatory periodic assessments to ensure a win-win situation between themselves and borrowers. Service of this nature is more pertinent than mere penalization of loan default. Borrowers transformed into sound financial positions are most likely to reduce the levels of default. Furthermore, they are likely to transact more with the bank to the extent of ensuring an increase in non-interest revenue through BASF and transactional fees.

We propose a long-term structured approach that is termed periodic assessments, intended to provide a solution to the prevention of self-destructive behaviors referred here in as wanton. This is particularly important in terms of loans whose repayment terms are longer (more than one year). Banks should have an advisory session annually with borrowers detailing the consequences of changes to macroeconomic fundamentals and their impact on terms and conditions of loans. Several benefits accrue both to the bank and the borrower. Loan defaults can be mitigated and as captured by Behr et al. (2011), longer lending relationships aid in reducing information asymmetries to the benefit of micro-borrowers. BASF can be argued due to the gargantuan nature of solutions to inherent wanton behaviors exhibited by borrowers. It is not surprising, then, that Khieu and Yi (2012) should emphasize the importance of macroeconomic conditions in determining loan recovery rates. Given the significance of changes in macroeconomic fundamentals, the pre-default era should be characterized by an assessment of borrower behavior to changes in macroeconomic conditions before the bank experiences default.
The idea of generating non-interest income through periodic assessment of borrower activity was also mooted by Kohler (2014) when he gave emphasis to the fact that retail oriented banks with a huge focus on lending and deposit taking tend to become more stable through the increase (in the sense of having a higher $z$-score) in non-interest income. Even though Delpachitra and Lester (2013) concluded that pursuing non-interest income and revenue diversification reduced profitability and did not improve the overall default risk of banks, it is argued here that based on pursuance of periodic assessments of $\mathrm{WB}$, and moving away from traditional techniques, banks can show increases in profitability as well as an improvement in the overall default risk. Firstly, income generated from the assessments will improve profitability and secondly, the assessments themselves are intended to highlight areas of concern in order for borrowers to safeguard against the pernicious effects of default. A common contention is that banks delving into non-interest income activities show higher levels of risk and higher insolvency risk than banks which mainly supply loans (Lepetti et al., 2008). However, the same banks which mainly supply loans could get to the same levels of higher risk and higher insolvency if they do not partake in efforts to address the potential effects imposed by borrowers' WB thereby losing out on generating non-interest income.

It is asserted here that the effects of assessing borrower behavior and in particular WB can provide a fertile platform for profitability than what can be achieved from the after effects of counselling borrowers who are already in default. Moreover, the former approach is active whilst the latter is reactive. Collins (2007) put it succinctly by revealing that counselling mitigates borrower movement to severe stage of foreclosure. Hence, counselling based on longer durations matching loan terms through periodic assessments of WB before default becomes pertinent and imperative. The longer it is done, the better the success rate, not forgetting the commensurate accrual of BASF and WHF.

The levied BASF and WHF are a means to improve non-interest revenue but they are not an 
end by themselves. The detection of WB is after the process of credit scoring which basically is used to identify those characters who do not pay because of cash flow problems (won't pay) and those that do not pay because of a lack of willingness to pay (won't pay) (Bravo et al., 2015). Periodic assessments of WB transcend this assertion by looking at those who do not suffer from the alluded scenarios of cash flow and willingness but who neglect to pay attention to fundamentals such as interest rates that could later impact the cash flows culminating to default. The emphasis is on neglect which basically equates to wanton behavior.

The central theme to raising BASF is the existence of and recognition that procyclicality can be the root cause of banking crisis which can be addressed through countercyclical measures, an argument that was put forward by Ben and Eli (2008) in describing the nuances of the 2007-2008 financial turmoil. In this article, countercyclical is in the form of, and is akin to advise rendered to borrowers pertaining to all fundamentals that borrowers need to be conscious of with regards to behavioral standards aligned to loan terms. For instance, low interest rates that preceded the 2007-2009 financial crisis could have been highlighted to borrowers in relationship to the likelihood of increases in interest rates in the future and the commensurate potential ramifications to the borrower ability to pay.

\section{METHODS}

A trend analysis of only mortgage loans was carried out over a five-year period from 2012 to 2016 and a corresponding credit losses analysis was carried out for the same period. Three banks were selected, bank A, B and C. A potential BASF income measure was generated using a fee proposed based on a percentage below that of the minimum average credit loss. The fee was calculated using the assumed proposal percentage to the accumulated mortgage loans over the five-year period. The periodic assessments calculated are for each year which meant the occurrence of a further four-year periodic assessments were not calculated. The potential BSAF which was then calculated was based on a once off periodic assessment for assets in year 2012 up to 2016. Furthermore, a WHF was calculated in line with the borrowers' amount whose behavior exhibited WB as outlined in terms and conditions. To reflect the alignment of loans to Basel III risk weights, we categorized WHF based on the type of asset created assigning a higher fee to higher risk weighted assets and lower fees to corresponding lower risk weighted assets. This fee is only meant for borrowers whose defaults are an outcome of WB. Since we focused on mortgage loans, we assign a WHF corresponding to the risk weight of mortgage loans and we termed it $\mathrm{m}$. WHF is also levied periodically but only on borrowers exhibiting WB. We then summed up income generated based only on BASF. Thereafter, we brought the potential income from $\mathrm{WH}$ and add it to obtain the overall income.

\section{EFFECT OF BASF ON OVERALL INCOME}

Bank loans vary in terms of size and term. What we suggest here is that the BASF be instituted in line with the loan term. Hence, if a loan term is say, five years, then an annual advice based on the above stated levers should be rendered to borrowers. This does not mean where a lever is not reflected, then no advise is proffered but rather advise be given for existing or potential occurrence. Hence, the borrower receives advise periodically (five times) until his loan is repaid. This ensures a constant fee generation which is not exposed to volatility conditions as espoused in interest income fee.

Looking at a five-year period of the top three SA banks in terms of mortgage loans, i.e. home loans and commercial mortgages excluding corporate and investment banking, instituting a minimal $0.05 \%$ (way below average credit losses basis points), BSAF of the total values, we can see the potential income generating capabilities as shown in Tables 1,2 and 3. Bank A shows a potential income of 403 million, which is 1 percent of the total headline earnings. Bank $B$ also displays a potential income of 630 million, which also is 1 percent of headline earnings. Bank $\mathrm{C}$ likewise exhibits great potential of 811 million income, which is also a $1 \%$ potential percentage contribution to headline earnings for the period in question. 


\section{Bank A}

Table 1. Bank A potential BASF income as a function of mortgage loans and credit losses

\begin{tabular}{|c|c|c|c|c|c|c|}
\hline Year & 2016 & 2015 & 2014 & 2013 & 2012 & Cumulative total \\
\hline Mortgage loan & 171,099 & 167,277 & 159,296 & 155,878 & 154,148 & 807,698 \\
\hline *Potential income & 85.55 & 83.63 & 79.65 & 77.94 & 77.07 & 403.84 \\
\hline Headline earnings & 11,465 & 11,162 & 10,188 & 8,670 & 7,483 & 48,968 \\
\hline${ }^{* *}$ Credit losses & $0.68 \%$ & $0.77 \%$ & $0.79 \%$ & $1.06 \%$ & $1.05 \%$ & - \\
\hline
\end{tabular}

Note: ${ }^{\star}$ Potential income $-0.8 \%$ of cumulative mortgage loan totals. ${ }^{*}$ Credit losses $-0.87 \%$ average credit loss.

\section{Bank B}

Table 2. Bank B potential BASF income as a function of mortgage loans and credit losses

\begin{tabular}{|c|c|c|c|c|c|c|}
\hline Year & 2012 & 2013 & 2014 & 2015 & 2016 & Cumulative total \\
\hline *Mortgage loan & 227,138 & 221,876 & 268,781 & 273,078 & 270,876 & - \\
\hline Potential income & 113,57 & 110,94 & 134,39 & 136,54 & 135,44 & 630,88 \\
\hline Headline earnings & 10,419 & 11,843 & 13,032 & 14,287 & $14,9 \mathrm{bn}$ & 64,481 \\
\hline **Credit losses & $1.16 \%$ & $0.92 \%$ & $1.02 \%$ & $1.20 \%$ & $1.59 \%$ & - \\
\hline
\end{tabular}

Note: ${ }^{\star}$ Potential income $-1 \%$ of cumulative mortgage loan totals. ${ }^{*}$ Credit losses $-1.18 \%$ average credit loss.

\section{Bank C}

Table 3. Bank C potential BASF income as a function of mortgage loans and credit losses

\begin{tabular}{c|c|c|c|c|c|c}
\hline \multicolumn{1}{c}{ Year } & $\mathbf{2 0 1 6}$ & $\mathbf{2 0 1 5}$ & $\mathbf{2 0 1 4}$ & $\mathbf{2 0 1 3}$ & $\mathbf{2 0 1 2}$ & Cumulative total \\
\hline Mortgage loan & 325,867 & 310,330 & 317,069 & 339,687 & 330,849 & - \\
& & & & & \\
*Potential income & 162,93 & 155,17 & 158,53 & 169,84 & 165,42 & 811,89 \\
Headline earnings & 14,599 & 13,376 & 17,323 & 20,006 & 19,269 & $84,573 \mathrm{bn}$ \\
\hline${ }^{* *}$ Credit losses & $0.49 \%$ & $0.87 \%$ & $1.00 \%$ & $1.12 \%$ & $1.05 \%$ & $0.91 \%$ \\
\hline
\end{tabular}

Note: ${ }^{\star}$ Potential income $-1 \%$ of cumulative mortgage loan totals. ${ }^{*}$ Credit losses $-0.91 \%$ average credit loss.

\section{MODELLING FRAMEWORK AND TOTAL EFFECT ON INCOME}

Using average credit losses for all the banks over the five-year period, it is implied here that a fraction of the credit loss could have been avoided if the periodic assessments were carried out as suggested. Assigning alpha to the potential reduction, we show that for bank A the total benefit is:

$$
B A S F+\alpha \cdot b p,
$$

where $b p$ represents basis points, and the total income adjusts to:

$$
T I=N I I+\alpha \cdot b p+N I R+B A S F,
$$

where TI represents total income. $T I_{a}$ represents total income for bank $\mathrm{A}$.

Which becomes

$T I_{a}=N I I+\alpha \cdot 87 \cdot b p+N I R+B A S F$

Bank B

$$
B S F A+\alpha \cdot b p,
$$

and the total income adjusts to:

$$
T I_{b}=N I I+\alpha \cdot 118 \cdot b p+N I R+B A S F,
$$

where $T I_{b}$ represents total income for bank B.

Bank C

$$
B A S F+\alpha \cdot b p,
$$

and the total income adjusts to: 


$$
T I_{c}=N I I+\alpha \cdot 91 \cdot b p+N I R+B A S F,
$$

where $T I_{c}$ represents total income for bank C.

In order to investigate how banks can adjust the total income after taking WHF into consideration, we estimate the following specifications:

$\beta$ for the proportion of loans subjected to default based on WB, and $m \beta$ becomes the WHF collected.

Therefore, the total income where default is recorded adjusts to:

$$
\begin{aligned}
& T I_{a}=N I I+\alpha \cdot 87 \cdot b p+N I R+B A S F+m \beta, \\
& T I_{b}=N I I+\alpha \cdot 118 \cdot b p+N I R+B A S F+m \beta, \\
& T I_{c}=N I I+\alpha \cdot 91 \cdot b p+N I R+B A S F+m \beta .
\end{aligned}
$$

Using the cumulative figures for potential BASF as calculated earlier on in Tables 1, 2 and 3, bank A adds a huge 403,84 million Rand with bank B adding 630,88 million, whilst bank $\mathrm{C}$ adds 811,89 million over a five-year period. Hence:

$$
T I_{a}=N I I+\alpha \cdot 87 \cdot b p+N I R+403.84+m \beta,
$$

$T I_{b}=N I I+\alpha \cdot 118 \cdot b p+N I R+630.88+m \beta$,

$$
T I_{c}=N I I+\alpha \cdot 91 \cdot b p+N I R+811.89+m \beta .
$$

Bearing in mind that some borrowers would certainly exhibit WB and additional WHF gets added to BASF, banks can have a significant revenue generation method which is based on efforts to strengthen borrowers' capacity to meet their loan obligations. It is assumed here that $m \beta$ which is a reactionary fee would decrease progressively for a particular borrower provided he takes to heart the periodic advice rendered to him from the beginning of the loan period. However, as $m \beta$ emanating from one borrower decreases, a countervailing but positive income is generated from new borrowers who still need to be given borrower advise. By and large, repeat borrowers would be expected to pay little to none WHF based on their attained knowledge. Hence, part of the total income in the form of $m \beta$ is always dependent upon borrower characteristic-new, existing or repeat. By the same token, BASF would increase or decrease depending on the magnitude of the loans. In this case, the size of BASF is indirectly impacted by the amount of capital the bank has as dictated by Basel III regulation.

\section{CONCLUSION}

By examining the effect of carrying out periodic assessments on borrower behavior that could work in tangent to loan terms, banks can benefit from two angles. The first being that a service fee called BASF can be levied to justify the amount of value added to borrowers pertaining to behavioral conduct that could lead to defaults. Secondly, the amount of credit losses due to the same action of credit enhancements tend to reduce thereby increasing the financial benefit to banks. This interpretation is important in demonstrating the earning power at the disposal of banks that can emanate from periodically providing the much sought-after advice based on wanton behaviors that ignore, violate or countervail loan terms. Finally, a fee that is aligned to the risky of the asset based on Basel III risk weights is added giving banks an opportunity to gain the much-needed non-interest income justified by interventions to protect borrowers from embarking on self-destructive behaviors that may have a corresponding domino effect on repayment capabilities to the banks.

\section{REFERENCES}

1. Acharya, V., \& Naqvi, H. (2007). The seeds of a crisis: A theory of bank liquidity and risk-taking over the business cycle (No. 8851). CEPR Discussion papers.

2. Agarwal, S., \& Evanoff, D. (2014). Predatory lending and the subprime crisis. Journal of financial economics, 113(1), 3952. Retrieved from https://www. sciencedirect.com/science/article/ pii/S0304405X14000397

3. Anagnostopoulou, S. C., \& Drakos, K. (2016). Bank loan terms and conditions: Is there a macro-effect? Journal of research in international business and finance, 37, 269-282. Retrieved from https://www.sciencedirect.com/science/article/pii/ S0275531915300738 
4. Behr, P., Entzian, A., \& Guttler, A. (2011). How do lending relationships affect access to credit and loan conditions in microlending? Journal of banking and finance, 35(8), 2169-2178.

5. Bravo, C., Thomas, L. C., \& Weber, R. (2015). Improving credit scoring by differentiating defaulter behavior. Journal of the operational research society, 66(5), 774-781. Retrieved from https://link.springer.com/ article/10.1057\%2Fjors.2014.50

6. Bucks, B., \& Pence, K. (2008). Do borrowers know their mortgage terms? Journal of urban economics, 64(2), 218-233.

7. Cohen, B., \& Remolona, E. (2008) The unfolding turmoil of 20072008: Lessons and responses. Retrieved from http://www.rba. gov.au/publications/confs/2008/ cohen0remolona.htm/

8. Collins, J. M. (2007). Exploring the design of financial counseling for mortgage borrowers in default. Journal of family and economic issues, 28(2), 207-226.
9. Delpachitra, S., \& Lester, L. (2013). Non-interest income: Are Austrian banks moving away from their traditional businesses? Journal of applied economics and policy, 32(2), 190-199.

10. Graafland, J. J., \& Vande Ven, B. W. (2011). The credit crisis and the moral responsibility of professionals in finance. Journal of business ethics, 103(4), 605-619.

11. Grosse, R. (2012). Bank regulation, governance and the crisis: A behavioral finance view. Journal of financial regulation and compliance, 20(1), 4-25.

12. Khieu, H. D., \& Yi, H. C. (2012). The determinants of bank loan recovery rates. Journal of banking and finance, 36(4), 923-933.

13. Kohler, M. (2014). Does noninterest income make banks more risky? Retail versus investment oriented banks. Review of financial economics, 23(4), 182-193.

Retrieved from https://www. sciencedirect.com/science/article/ pii/S1058330014000354
14. Lepetti, L., Nys, E., Rous, P., \& Tarazi, A. (2008). Bank income structure and risk: An empirical analysis of European banks. Journal of banking finance, 32(8), 1452-1467.

15. Louis, D. P., \& Metaxas, V. L. (2012). Macroeconomic and bank-specific determinants of non-performing loans in Greece: A comparative study of mortgage business and consumer loan portfolios. Journal of banking and finance, 36(4), 1012-1027. Retrieved from https://www. sciencedirect.com/science/article/ pii/S0378426611002895

16. Quercia, R. G., Stegman, M. A., \& Davis, W. R. (2007). The impact of predatory loan terms on subprime foreclosures: The special case of prepayment penalties and balloon payments. Journal of housing policy debate, 18(2), 311-346.

17. Trautman, S. T., \& Vlazu, R. (2013). Strategic loan defaulters and coordination: An experimental analysis. Journal of banking and finance, 37(3), 747-760. 